\title{
A NEW MANUAL RESPIRATOR
}

\section{IAIN M. MAOK.4Y, M.D, F.A.C.A."}

A CONSIDERABLE VARIETY of respurators is in use today for ventilation of the anaesthetized subject. Some are mechanically, some manually operated. While recognizing the deserved popularity of the mechanical type I believe that the manual respurator has its place in clinical anaesthesia.

The device presented here requires no notive power other than the hand of the anaesthetist. This is, of course, an apparent disadvantage as the anaesthetist must himself ventilate the patient throughout the procedure. However, our experience has shown us the desirability of providing an assistant for most intrathoracic cases, even when the ana'esthetist is equipped with a mechanical respurator. We have also found that the device described below causes much less fatigue in arm and hand than ventilation by the ordinary method, using the standard large bag of the Hejdbrink or other circle absorption machine.

Neither compressed gases nor suction are required for operation of this respirator. It will adapt readily to any anaesthetic gas machine using either circle absorption or to-and-fro absorption of carbon dioxide. Either the closed system with maximal carbon dioxide absorption or a high gas flow and carbon dioxide blow-off may be used.

Another advantage of this device is its simplicity. Damage to the apparatus is unlikely and repair is not difficult. Spare parts are easily obtained although seldom required. All necessary cleaning and sterilization may be done easily.

A very important advantage is the low cost of this respirator in comparison with the mechanical apparati. This is, of course, of great importance in the large hospital in which there may be four or five intrathoracic procedures in progress at one time. The high cost of the mechanical ventilators may make their purchase in quantity impossible, whereas several respirators of the type described here could be made available for the price of one automatic ventilator.

The device consists essentially of a standard Coxeter-Mushin bellows This has been hinged to impart stability and can be clamped to the edge of an operating table (Fig. 1). The hinge is devised to open automatically if the bellows overfills and may be opened with one motion of the hand if a free bellows is desired $\mathrm{A}$ handstrap is attached to the bellows top.

The bellows is connected by a length of standard, wide-bore, corrugated rubber tubing and a special bag-mount to a gas machine (Fig. 2). As illustrated the bag-mount carries a standard Heidbrink rebreathing bag. A two-way widebore valve, interposed between the two bags, allows either an intermittent positive pressure technique or alternating positive and negative pressures to be used at any time An air intake valve is inserted in the bag-mount. If it is desired the bellows may be fitted directly onto the special bag-mount so that it projects to the side of the absorber.

'Department of Anaesthesia, University of Toronto, and Toronto General Hospital. 


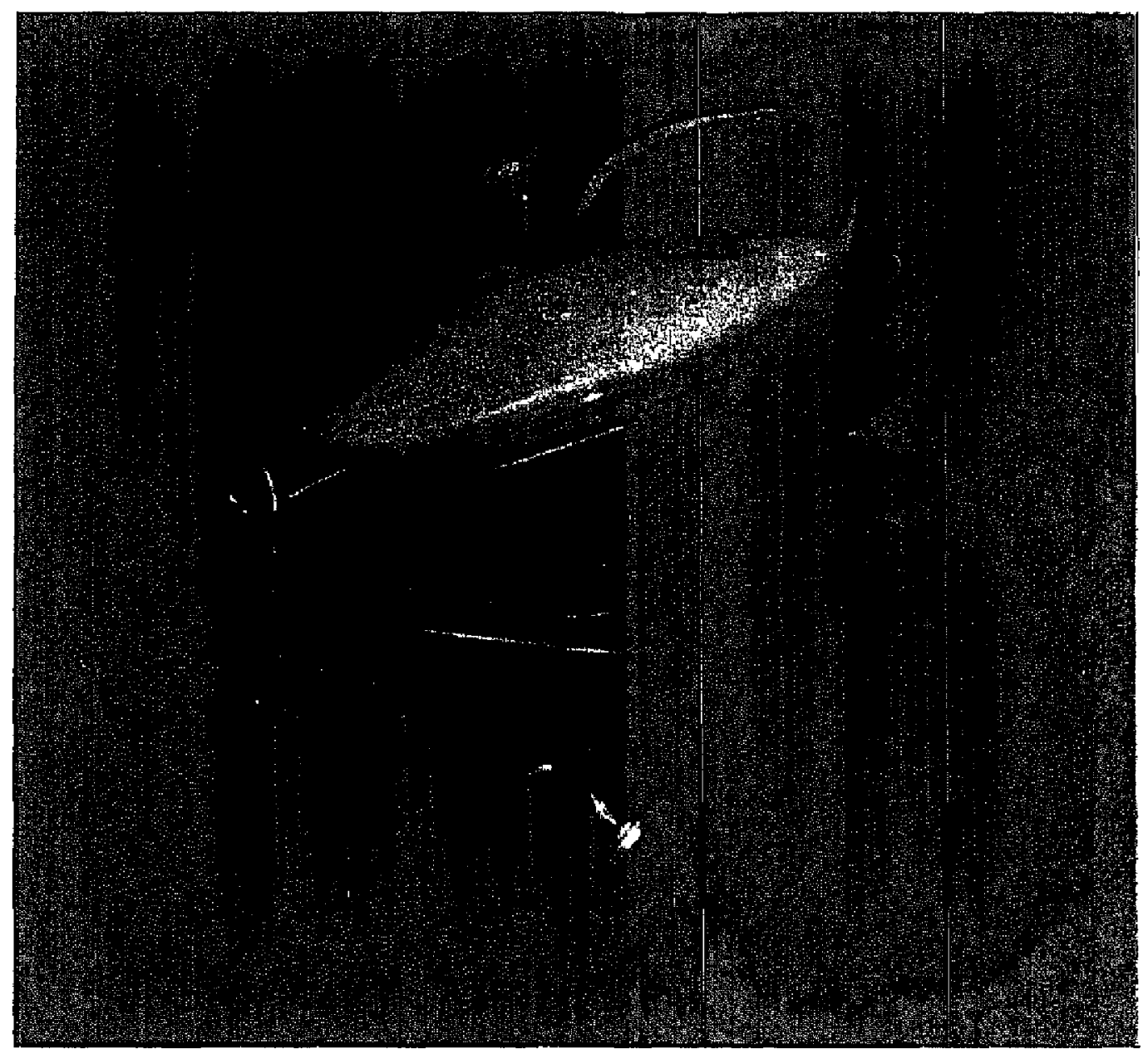

FIGURE 1 The band-operated ventalating Bellows of the respirator clamped to the head of an operating table

An anerord manometer is attached by a length of flexible rubber tubing to a wide-bore T-piece introduced into the respuratory circuit just proximal to the endotracheal tube ( $F 1 g$ 2) Posibve pressures are regulated by the expiratory valve of the gas machune Negative pressures are determined from the manometer The apparatus described above has been used in more than sxty surgical procedures during the past eight months Approximately two-thirds weie intrathoracic procedures, most of the others, upper abdominal

Pressures ranging from $+20 \mathrm{~cm} \mathrm{H}_{2} \mathrm{O}$ to $-10 \mathrm{~cm} \mathrm{H} \mathrm{H}_{\mathrm{a}} \mathrm{O}$ were used in these cases In some, only intermittent positve pressure was utlized but in the majority both positive and negative pressures were used

Apnoea is easly acheved and maintaned with this apparatus Artencl and venous $\mathrm{pH}$ levels have been determined in several patients undergoing upper abdominal or intrathoracic surgery $\mathrm{A}$ pH of 75 was consistently achieved in this series In one case, by deliberate over-ventilation, a venous $\mathrm{pH}$ of 77 was attaned indicating a probable arterial $\mathrm{pH}$ of 78 or more and a true respiratory 


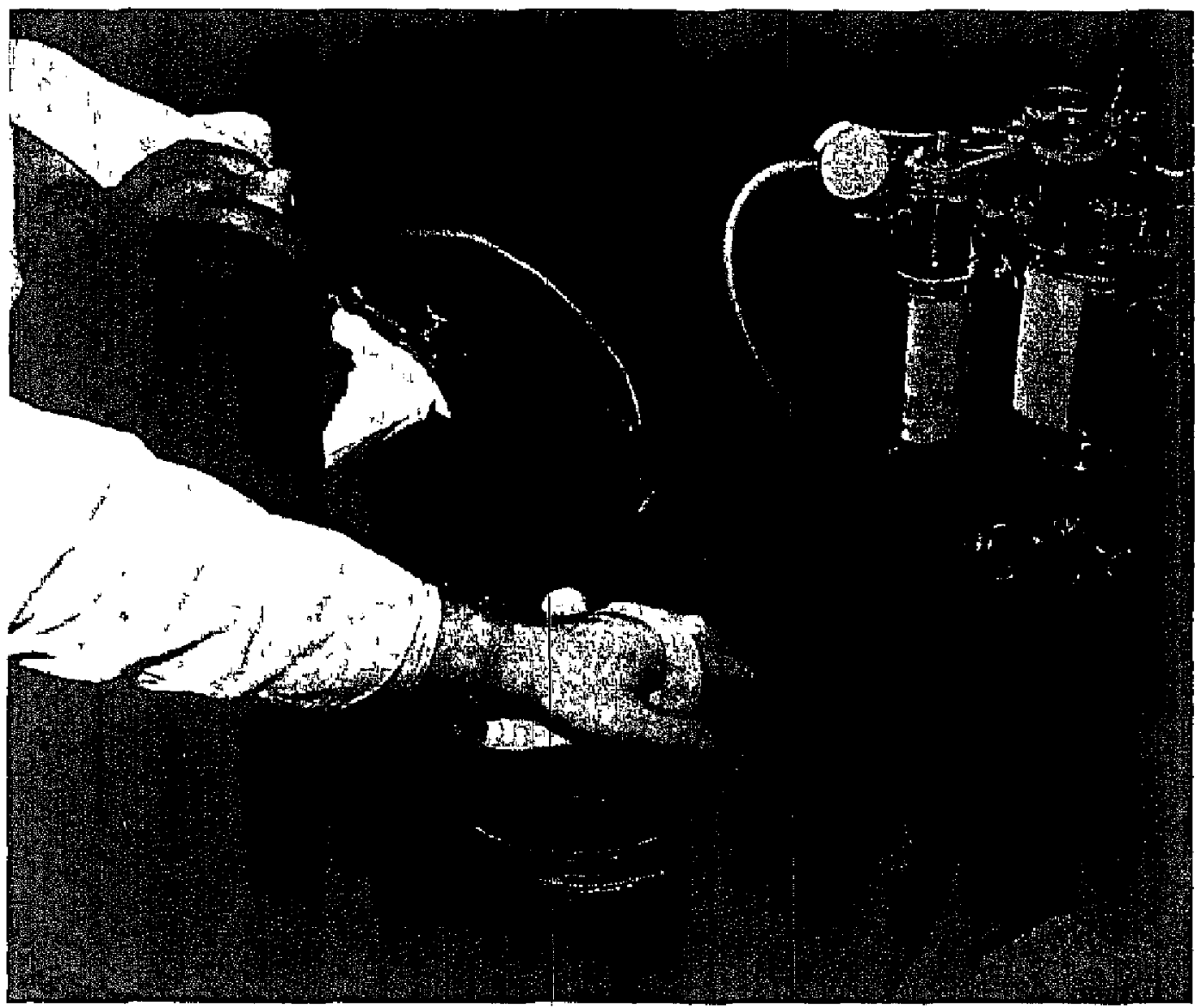

Ficuse 2 The respirator equpment is shown in use, attached to the head of a Heidbrink anuesthetic gas machine

alkalosis, the normal range of blood $\mathrm{pH}$ being between 735 and 745 Although a high degree of alkalaemia is not necessarly desirable this demonstrates the efficiency of the apparatus in carbon dioxide elimmation

A patient's earlhest attempt to escape from respiratory control can be immediately detected by the hand of the operator and corrected much more quickly than is possible wth a mechanical respirator, he can pievent the patient from having to "fight" control With the mechanical type of respirator such escape is not so lukely to occur due to the almost invariable induction of a tuue respiratory alkalosis The desirability of this is subject to debate

The direct contiol which the anaesthetıst has over the manual respurator allows the lung to be immobilized immedrately at anv point in either phase of respiration and held stall for as long as is required by the surgeon Mediastinal movement may, of course, be minthized in the same way, more easily than with a mechamical device

The apparatus discussed above was made to my specifications by British Oxygen Canada Limited They are piepared to supply a somewhat more streamlined model on order and at low cost 


\section{SUMMARY}

In spite of the popularity of mechanical respirators today the manual respirator is still of value. A new device of the latter type is described here, exhibiting the desirable features of adaptability to any gas machine, circuit or ventilation technique; simplicity of construction and design; low cost and economy of operation; portability; and efficiency in both oxygenation and carbon dioxide elimination.

\section{RÉSUMÉ}

Bien que le respirateur mécanique jouisse d'une grande popularité aujourd'hui, le respirateur opéré manuellement a aussi une place en anesthésie.

Il est moins fatiguant à employer que le ballon de la machine à gaz régulière, le modèle décrit ci-contre s'adapte à toute méthode de ventilation et ne requiert pas d'autre source de gaz ou d'énergie. Le dessin en est simple. La réparation, si elle devient nécessaire, peut se faire facilement et il en est ainsi pour le nettoyage et la stérilisation de l'appareil. Son prix modique lui donne un avantage bien défini sur le respirateur type mécanique.

Le plan consiste en un genre d'accordéon qui peut être fixé à la table d'opération ou inséré dans la machine à gaz (Fig. 1). Une longueur de tubes de caoutchouc ordinaires, de large diamètre et un embout spécial complètent le montage (Fig. 2). Une valve à deux directions permet l'emploi de l'un ou l'autre des deux ballons. Des pressions intrapulmonaires variant entre $+20 \mathrm{~cm}$. $d^{\prime} \mathrm{H}_{2} \mathrm{O}$ et $-10 \mathrm{~cm}$. d' $\mathrm{H}_{2} \mathrm{O}$ sont employées et sont enregistrées par un manomètre aneroide attaché au circuit par un tube en $\mathrm{T}$ à grandes ouvertures (Fig. 2).

On peut obtenir facilement une apnée avec cet appareil et on peut maintenir expérimentalement un $\mathrm{pH}$ sanguin de 7.5 et plus. A part cela, il est possible de découvrir et de corriger rapidement les fuites provenant du contrôle respiratoire. Avec cet apparell, on peut rédure à volonté les mouvements du poumon et du médiastin.

On peut se procurer ce respirateur à prix modıque à la compagnie "Britısh Oxygen Canada Ltd." 